\title{
EFEKTIFITAS JUS MENTIMUN DALAM MENURUNKAN TEKANAN DARAH PADA PASIEN HIPERTENSI
}

\author{
Ramdya Akbar Tukan ${ }^{1}$ \\ 1.Jurusan Keperawatan Fakultas Ilmu Kesehatan Universitas Borneo Tarakan \\ *Email: ramdyalovaa@gmail.com
}

\begin{abstract}
Abstrak
Hipertensi adalah peningkatan darah sistolik $\geq 140 \mathrm{mmHg}$ atau peningkatan tekanan darah diastolik $\geq 90 \mathrm{mmHg}$. Hipertensi dapat mengganggu aktifitas, berbagai macam terapi telah ditawarkan untuk menurunkan tekanan darah, salah satunya terapi jus mentimun. Artikel ini secara komprehensif merangkum, menilai dan meninjau literatur yang tersedia tentang terapi menurunkan tekanan darah tinggi yaitu dengan buah mentimun. Metode: yang di gunakan dalam Literature review diawali dengan pemilihan topik, kemudian ditentukan keyword untuk pencarian jurnal menggunakan Bahasa Inggris dan Bahasa Indonesia melalui beberapa database antara lain Google Scholar, Ebscho, dan Pro Quest. Pencarian ini dibatasi untuk jurnal mulai tahun 2010 sampai dengan tahun 2015. Keyword Bahasa Inggris yang digunakan adalah "Hypertension and Therapy", "Hypertension and Cucumber Juice", "Effect of Cucumber Juice Therapy on Hypertension", Untuk bahasa Indonesia menggunakan kata kunci "Hipertensi, Efektivitas, Terapi, Jus Mentimun". Hasil: terapi jus mentimun pada kelompok perlakuan dari beberapa hasil penelitian yang penulis temukan, bahwa jus mentimun dapat menurunkan tekanan darah, hasil tersebut sebagai berikut ; hasil penelitian dari Lebalado (2014) menyatakan bahwa konsumsi 150 ml jus mentimun selama 7 hari dapat menurunkan tekanan darah sistolik dan diastolik pada laki-laki dan perempuan hipertensi secara signifikan. Sedangkan menurut hasil penelitian Khusnul dan Munir 2012 menyatakan bahwa ada pengaruh bermakna dari pemberian jus mentimun terhadap penurunan tekanan darah, penurunan terbesar terjadi pada 2 jam dan setelah perlakuan hari ke 4 dan 5 setelah perlakuan pemberian jus mentimun pada lansia dengan penyakit hipertensi tanpa penyakit penyerta. Diskusi: Ini berarti konsumsi jus mentimun dapat membantu menurunkan tekanan darah pada pasien hipertensi.
\end{abstract}

Kata kunci : Hipertensi, Jus Mentimun, Tekanan Darah

\begin{abstract}
Literature Review: Effectiveness of Cucumber Juice in Lowering Blood Pressure in Hypertensive Patients. Hypertension is an increase in systolic blood $\geq 140 \mathrm{mmHg}$ or increased diastolic blood pressure $\geq 90 \mathrm{mmHg}$. Hypertension is able to disturb activity, various therapies have been offered to lower blood pressure, and one of them is cucumber juice therapy. This article comprehensively summarizes, assesses and reviews the available literature on low blood pressure therapies with cucumber. Method: Literature review begins with topic selection, then keyword is determined for journal search using English and Bahasa Indonesia through several databases such as Google Scholar, Eschol, and Pro Quest. This search is limited to journals from 2010 to 2015. Keywords of English used are "Hypertension and Therapy", "Hypertension and Cucumber Juice", "Effects of Cucumber Juice Therapy on Hypertension", For Indonesian language use the keyword "Hipertensi, Efektivitas, Terapi, Jus Mentimun". Results: cucumber juice therapy in the group of treatment from several research results that the authors found, that cucumber juice can lower blood pressure, the results are as follows; the results of the study from Lebalado (2014) stated that the consumption of $150 \mathrm{ml}$ of cucumber juice for 7 days can significantly reduce the systolic and diastolic blood pressure in men and women of hypertension significantly. Meanwhile, according to the results of Khusnul and Munir 2012 study stated that there is a significant influence of cucumber juice on blood pressure decrease, the greatest decrease occurred at 2 hours and after treatment day 4 and 5 after treatment of cucumber juice in elderly with hypertension disease without coexistent disease. Discussion: This means consumption of cucumber juice can help lower blood pressure in hypertensive patients.
\end{abstract}

Keywords: Hypertension, Cucumber Juice, Blood Pressure 


\section{Latar Belakang}

Hipertensi merupakan penyakit yang sering dijumpai di Indonesia. Penyakit ini dapat menyerang siapa saja dari berbagai kelompok umur dan kelompok sosial ekonomi. Dengan semakin bertambahnya usia, kemungkinan seseorang menderita hipertensi semakin besar. Pengaruh usia terhadap kemunculan stres juga sering terjadi (Tilong,2012). Prevalensi hipertensi meningkat seiring dengan meningkatnya usia. Hal ini disebabkan karena tekanan arterial yang meningkat sesuai dengan bertambahnya usia, terjadinya regurgitasi aorta, serta adanya proses degeneratif (Lailatul, 2007).

Prevalensi hipertensi di Indonesia yang didapat melalui pengukuran pada umur $\geq 18$ tahun sebesar 25,8\%. Prevalensi hipertensi di Indonesia yang didapat melalui kuesioner terdiagnosis tenaga kesehatan sebesar 9,4\%, yang didiagnosis tenaga kesehatan atau sedang minum obat sebesar $9,5 \%$. Jadi ada $0,1 \%$ yang minum obat sendiri. Responden yang mempunya tekanan darah normal tetapi sedang minum obat hipertensi sebesar $0,7 \%$. Jadi prevalensi hipertensi di Indonesia sebesar 26,5\% $(25,8 \%+0,7 \%)$ (Riskesdas, 2013)
Jika tidak segera ditangani maka akan terjadi komplikasi penyakit lain seperti serangan jantung atau stroke.

Penderita hipertensi dengan tekanan darah yang tinggi akan menjalani hidup dengan bergantung pada obat-obatan dan kunjungan teratur ke dokter untuk mendapatkan resep ulang dan check-up. Data WHO melaporkan dari $50 \%$ penderita hipertensi yang diketahui hanya $25 \%$ yang mendapat pengobatan, dan hanya $12,5 \%$ yang diobati dengan baik (adequately treated cases) karena mahalnya biaya yang diperlukan selama proses terapi (Depkes, 2012).

Salah satu terapi non-farmakologis yang dapat diberikan pada penderita hipertensi adalah terapi nutrisi yang dilakukan dengan manajemen diet hipertensi. Contohnya dengan pembatasan konsumsi garam, mempertahankan asupan kalium, kalsium, dan magnesium serta membatasi asupan kalori jika berat badan meningkat. DASH (Dietary Approaches to Stop Hypertension) merekomendasikan pasien hipertensi banyak mengkonsumsi buah-buahan dan sayuran, meningkatkan konsumsi serat, dan minum banyak air (Lewis, Hetkemper, \& Dirksen, 2004). Terapi 
diet merupakan terapi pilihan yang baik untuk penderita hipertensi. Terapi ini dapat dilakukan dengan mengkonsumsi sayuran yang dapat mempengaruhi tekanan darah, seperti mentimun.

Sebagai salah satu alternatif pengobatan nonfarmakologis, mentimun diharapkan dapat menjadi sebuah terobosan baru dalam mengatasi permasalahan hipertensi. Disamping mengandung zat-zat yang bermanfaat bagi kesehatan, mentimun juga terbilang jauh lebih murah dan ekonomis jika dibandingkan dengan biaya pengobatan farmakologis dan mudah diperoleh di tengah-tengah masyarakat. Berdasarkan penjelasan yang telah dikemukakan, maka penulis sangat tertarik untuk mereview beberapa literatur terkait tentang efektifitas mengkonsumsi jus mentimun untuk menurunkan tekanan darah pada pasien hipertensi. Sebagai rujukan evidence based agar perawat dapat menerapkannnya di komunitas pada pasien hipertensi yang sedang tinggi tekanan darahnya.

\section{Metode}

Metode yang di gunakan dalam Literature review ini diawali dengan pemilihan topik, kemudian ditentukan keyword untuk pencarian jurnal menggunakan Bahasa Inggris dan Bahasa Indonesia melalui beberapa database antara lain Google Scholar, Ebscho, dan Pro Quest. Pencarian ini dibatasi untuk jurnal mulai tahun 2010 sampai dengan tahun 2015. Keyword Bahasa Inggris yang digunakan adalah "Hypertension and Therapy", "Hypertension and Cucumber Juice", "Effect of Cucumber Juice Therapy on Hypertension", Untuk bahasa Indonesia menggunakan kata kunci "Hipertensi, Efektivitas, Terapi, Jus Mentimun”.

Jurnal dipilih untuk dilakukan review berdasarkan studi yang sesuai dengan kriteria inklusi. Kriteria inklusi dalam literature review ini adalah penggunaan Therapy Jus Mentimun terhadap penyakit Hipertensi. Pencarian menggunakan keyword diatas ditemukan 12 jurnal. Dari seluruh jurnal yang didapat yang sesuai dengan tema adalah 5 artikel, kemudian di cermati dan dilakukan Critical Appraisal.

\section{Hasil}

Literature review ini menelaah 5 artikel True Experiment, tentang pengaruh terapi jus mentimun terhadap peningkatan tekanan darah tinggi. Penelitian yang dilakukan oleh Khusnul dan Munir (2012), menjelaskan adanya 
penuruan tekanan darah pada pasien hipertensi dengan mengkonsumsi jus mentimun. Penelitian ini menggunakan sampel 20 orang lansia dengan hipertensi tanpa penyakit penyerta. Penelitian dilakukan selama enam hari, hari pertama tekanan darah lansia diukur untuk mendapatkan tekanan darah ratarata sebelum perlakuan, selanjutnya selama lima hari setiap lansia diberi perlakuan berupa jus mentimun sebanyak 100 gram dan diukur tekanan darahnya pada 2 jam, 6 jam, dan 9 jam setelah perlakuan. Hasil yang didapatkan pada penelitian ini adalah ada pengaruh bermakna dari pemberian jus mentimun terhadap penurunan tekanan darah, penurunan terbesar terjadi pada 2 jam dan setelah perlakuan hari 4 dan 5 setelah perlakuan pemberian jus mentimun.

Diperkuat lagi hasil dari penelitian kedua oleh Kharisna, Dewi dan Lestari (2010), pada penelitian ini bertujuan untuk memberikan terapi jus mentimun pada klien yang hipertensi dengan sampel penelitian sebanyak 30 orang, teknik pengambilan sampel yaitu purposive sampling. Sampel pada penelitian ini adalah wanita yang berusia 35-60 tahun, mempunyai tekanan darah $>140 / 90$ (MAP > 106), tidak obesitas
(18,5 < IMT < 27), tidak merokok, tidak mengkonsumsi alcohol, tidak memiliki masalah kesehatan selain hipertensi, terutama asam urat, dan tidak mengkonsumsi obat-obatan hipertensi selama diberikan perlakuan. Desain penelitian yang digunakan adalah Quasy Experiment dengan rancangan penelitian Non Equivalent Control Group. Penelitian ini dilakukan di Kecamatan Pekanbaru Kota wilayah kerja Puskesmas Pekanbaru Kota yang dimulai dari bulan Oktober 2009 hingga bulan Juni 2010. Hasil yang didapatkan pada grup intervensi adalah rata-rata tekanan arteri rata-rata (MAP) pada kelompok kontrol sebelum diberikan jus mentimun sebesar 117,9, sedangkan rata-rata tekanan arteri rata-rata (MAP) sesudah diberikan jus mentimun sebesar 104,2. Hal ini menunjukkan terjadi penurunan tekanan darah setelah diberikan intervensi, dimana selisih antara dua rata-rata pretest dan post-test pada kelompok khususnya analisa pada kelompok eksperimen adalah 13,8 dengan $\mathrm{p}$ value $=0,000$. Ini berarti konsumsi jus mentimun dapat membantu menurunkan tekanan darah pada pasien hipertensi. Kelebihan yang ditemukan setelah menelaah artikel yaitu dapat diaplikasikan intervensi ini pada klien 
yang mengalami peningkatan tekanan darah tinggi pada wanita.

Penelitian ketiga yang dilakukan oleh Lebalado (2014) juga membuktikan bahwa jus mentimun berpengaruh terhadap penurunan tekanan darah. Penelitian ini dilakukan selama 7 hari dengan sampel klien 38 orang terdiri dari laki-laki dan perempuan dengan tekanan darah sistolik 140 - $159 \mathrm{mmHg}$ dan diastolik 90 - 99 mmHg. Subyek kemudian dibagi menjadi 2 kelompok, yaitu kelompok kontrol dan perlakuan. Didapatkan hasil ada penurunan tekanan darah sistolik sebesar 2\% $(\mathrm{P}=0,077)$ dan peningkatan tekanan darah diastolik $1,1 \%(\mathrm{P}=0,419)$.

Penelitian ini menunjukkan bahwa jus mentimun berpengaruh terhadap hipertensi sehingga dapat diaplikasikan. Adapun kekuatan dari penelitian ini adalah adanya dua hasil yang signifikan antara jus mentimun dengan hipertensi, sehingga sangat aplikatif bila digunakan pada klien dengan peningkatan tekanan darah tinggi. Hal ini memberikan solusi akan penatalaksanaan hipertensi dan telah diterapkan dibeberapa komunitas. Penelitian keempat mentimun terbukti dapat menurunkan tekanan darah pada penderita hipertensi di Dusun Klaten Desa Brenggolo Kecamatan Plosoklaten
Kabupaten Kediri. Penelitian kelima adanya pengaruh pemberian jus mentimun terhadap tekanan darah pada penderita hipertensi.

Meskipun memiliki tujuan yang sama untuk membuktikan pengaruh jus mentimun terhadap penyakit hipertensi, namun penelitian-penelitian di atas memiliki perbedaan dalam penggunaan alat ukur, populasi dan sampel, serta waktu pembacaan hasil setelah penerapan intervensi. Hipertensi yang diangkat pada penelitian-penelitian ini disebabkan karena berbagai jenis hipertensi.

Pemberian jus mentimun cukup berpengaruh dalam menurunkan tekanan darah pada penderita hipertensi, sehingga diharapkan tenaga kesehatan khususnya perawat lebih aktif dalam memberikan penyuluhan tentang pemanfaatan mentimun (Cucumis Sativus) terhadap penurunan tekanan darah pada penderita hipertensi. (Ningsih, 2014).

Menurut Meilinasari mentimun dapat mengobati hipertensi karena kandungan mineralnya yaitu potassium, magnesium, dan pospor yang bersifat diuretik dengan kandungan air yang tinggi sehingga membantu menurunkan tekanan darah. Potasium umumnya 
banyak didapati pada beberapa buah dan sayuran. Buah dan sayuran yang mengandung potasium sangat baik di konsumsi penderita tekanan darah tinggi (Bangun, 2002). Mentimun terbukti dapat menurunkan tekanan darah pada penderita hipertensi maka hal ini disebabkan oleh adanya kandungan potassium, magnesium, dan pospor yang bersifat diuretik dan kandungan air yang tinggi sehingga membantu menurunkan tekanan darah.

\section{Implikasi terhadap Praktik}

\section{Keperawatan}

Literature review ini berimplikasi terhadap praktik keperawatan medikal bedah, tetapi hasil dari penelitian beberapa jurnal di atas tidak sepenuhnya bisa digeneralisasikan karena banyak faktor yang dapat mempengaruhi persepsi seseorang dalam merespon hipertensi, diantaranya adalah pengalaman masa lalu terhadap nyeri, perasaan cemas dan stres yang menyertai, budaya, usia, jenis kelamin, lingkungan, dan sistem pendukung (perhatian). Nyeri bersifat individual, dimana setiap individu akan merasakan reaksi dan persepsi nyeri yang berbedabeda. Respon nyeri seseorang dihubungkan dengan status mental atau psikologis terhadap stimulus fisik yang ada. Impuls nyeri diatur oleh mekanisme pertahanan di sepanjang sistem syaraf.

Beberapa istilah dan intervensi yang digunakan dalam artikel ini cukup jelas dan tidak menimbulkan makna ambigu dikarenakan jurnal nasional ini hanya membahas tentang efektivitas pemberian intervensi jus mentimun terhadap penurunan tekanan darah yang mudah dipahami dan diterapkan pada klien yang mengalami hipertensi. Penerapan pemberian jus mentimun pada klien yang mengalami hipertensi mempunyai nilai aplikabilitas yang tinggi, tidak terlepas dari banyaknya faktor pendukung dan penghambat yang ada. Penggunaan jus mentimun merupakan intervensi alami non invasif yang dapat diterapkan secara sederhana tidak selalu membutuhkan kehadiran ahli terapi, harga terjangkau dan tidak menimbulkan efek samping. Penilaian terhadap hipertensi klien sering dilakukan perawat selama proses keperawatan, sehingga tidak diperlukan waktu khusus untuk melakukan intervensi pemberian jus mentimun di ruangan, karena intervensi ini akan menimbulkan ketenangan. 


\section{Kesimpulan}

Hipertensi adalah peningkatan darah sistolik lebih besar atau sama dengan $140 \mathrm{mmHg}$ atau peningkatan tekanan darah diastolik lebih besar atau sama dengan $90 \mathrm{mmHg}$. Salah satu tehnik untuk mengurangi tekanan darah tinggi yaitu jus mentimun. Jus mentimun sebagai salah satu sumber kalium dan magnesium tambahan untuk memenuhi kebutuhan kalium dan magnesium harian dan sebagai makanan alternatif maupun komplementer dengan jenis makanan lain dalam menurunkan tekanan darah sistolik dan diastolik. Artikel ini secara komprehensif merangkum, menilai dan meninjau literatur yang tersedia tentang hipertensi dan terapi menurunkan tekanan darah tinggi yaitu dengan buah mentimun. Hasil terapi jus mentimun pada kelompok perlakuan dari beberapa hasil penelitian yang penulis temukan, bahwa jus mentimun dapat menurunkan tekanan darah, hasil tersebut sebagai berikut; hasil penelitian dari Lebalado (2014) menyatakan bahwa konsumsi 150 ml jus mentimun selama 7 hari dapat menurunkan tekanan darah sistolik dan diastolik pada laki-laki dan perempuan hipertensi secara signifikan. Sedangkan menurut hasil penelitian Khusnul dan
Munir 2012 menyatakan bahwa ada pengaruh bermakna dari pemberian jus mentimun terhadap penurunan tekanan darah, penurunan terbesar terjadi pada 2 jam dan setelah perlakuan hari ke 4 dan 5 setelah perlakuan pemberian jus mentimun pada lansia dengan penyakit hipertensi tanpa penyakit penyerta. Ini berarti konsumsi jus mentimun dapat membantu menurunkan tekanan darah pada pasien hipertensi. Dan hasil penelitian dari Kharisna, Dewi, dan Lestari. 2010 menunjukkan bahwa konsumsi jus mentimun dapat membantu menurunkan tekanan darah pada pasien hipertensi.

Hasil analisis penulis dari beberapa literature artikel ini menyebutkan bahwa ada penurunan tekanan darah tinggi pada pasien hipertensi dengan mengkonsumsi jus mentimun secara rutin. Oleh karena itu, jus mentimun sangat efektif digunakan untuk menurunkan tekanan darah tinggi pada pasien hipertensi. Konsumsi $150 \mathrm{ml}$ jus mentimun selama 7 hari dapat menurunkan tekanan darah.

\section{Referensi}

Bangun, AP.(2002). Terapi Jus dan Ramuan Tradisional Untuk Hipertensi. Jakarta: Agro Media Pustaka 
Depkes. (2012). Hipertensi Penyebab Utama Penyakit Jantung. Diakses tanggal 14 Oktober 2015 dari http://m.depkes.go.id Kharisna, Dewi dan Lestari. (2014). Efektifitas Konsumsi Jus Mentimun Terhadap Penurunan Tekanan Darah Pada Pasien Hipertensi. Diakses pada tanggal 12 Desember 2015. ejournal.unri.ac.id/index.php/J NI/article/download

Kusnul dan Munir. (2012). Efek Pemberian Jus Mentimun Terhadap Penurunan Tekanan Darah. Diakses pada tanggal 12 Desember 2015 www.journal.unipdu.ac.id/inde x.php/seminas/article/downloa d

Lailatul Muniroh, B. W. (2007). Pengaruh Pemberian Jus Buah belimbing dan Mentimun Terhadap Penurunan Tekanan Darah Sistolik dan Diastolik Penderita Hipertensi. Bagian Gizi Fakultas Kesehatan Masyarakat Universitas Airlangga , 25-34.

Lewis, S. M., Heitkemper, M. M., \& Dirksen, S. R. (2004). Medical surgical nursing: Assesment and management of clinical problems. Missouri: Mosby.

Lebalado. (2014). Pengaruh Pemberian Jus Mentimun (Cucumis sativus L.) Terhadap Tekanan Darah Sistolik Dan Diastolik Pada Penderita Hipertensi. Skripsi Universitas Diponegoro. Semarang

Ningsih. (2014). Pengaruh Pemberian Jus Mentimun Terhadap Penurunan Tekanan Darah Pada Penderita Hipertensi Di desa sawahan Porong
Sidoarjo.Jurnal skripsi. http://repository.poltekkesmaja pahit.ac.id/index.php/S1KEP/article/view/145/115

Ponggohong, Rompas dan Ismanto. (2015). Pengaruh Pemberian Jus Mentimun Terhadap Tekanan Darah pada Penderita Hipertensi Di Desa Tolombukan Kec. Pasan Kab. Minahasa Tenggara Tahun 2015. Diakses pada tanggal 15 Desember 2015. ejournal Keperawatan (e-Kp) Volume 3 Nomor 2, Mei 2015

Riskesdas. (2013). Riset Kesehatan Dasar.Diperoleh tanggal 1 Desember 2014 diakses dari situs http://depkes.go.id.

Suryono dan Suyanto Agus. (2010). Efektivitas Juice Mentimun Terhadap Penurunan Tekanan Darah. Diakses pada taggal 15 Desember 2015. http://lppm.akperpamenang.ac. $\mathrm{id} / \mathrm{wp}-$ content/uploads/2015/05/0307. pdf. Jurnal AKP No. 37 3, 1 Januari - 30 Juni 2011 